\section{Sodium Hypochlorite Concentration, Temperature, and Seed Age Influence Germination of Sweet Pepper}

\author{
E.M. Khah \\ Home Products Handling Cooperative Administration, 27 Karolou Street, \\ Athens 104 37, Greece
}

\section{H.C. Passam \\ Department of Horticulture, Agricultural University of Athens, 75 Iera Odos, Votanikos, Athens 118 55, Greece}

Additional index words. Capsicum annuum, aging

Abstract. The effects of $\mathrm{NaOCl}$ on the germination behavior of seeds of sweet pepper (Capsicum annuum L. cv. E-84066) were related to the concentration of NaOCl, treatment duration, solution temperature during treatment, incubation temperature during germination, and the age of the seed. Rate and percentage of germination were slower and lower, respectively, when seeds were exposed to $3 \% \mathrm{NaOCl}$ solution at $35 \mathrm{C}$ for 20 or $40 \mathrm{~min}$. When treatment time and temperature were reduced, or the $\mathrm{NaOCl}$ concentration lowered, the adverse effects were less. Fresh seeds were more sensitive than seeds that had been stored for $\mathbf{1 0}$ months at ambient temperature, and inhibition of germination was greater when the incubation temperature during germination was lower or higher (15 or $35 \mathrm{C})$ than the optimum (25C).
Treatment of seeds with hypochlorite solutions is known to reduce the losses in germination caused by pathogens. It may also bring about changes in seed metabolism that additionally affect germination (Thomas, 1981).

The published effects of $\mathrm{NaOCl}$ on the germination of pepper seed are conflicting. Thus, $\mathrm{NaOCl}$ has been reported to either promote (Fieldhouse and Sasser, 1975; Macit, 1981) or inhibit (McCollum and Linn, 1955) germination, or to reduce the rate but not the total germination (Cantliffe and Watkins, 1983). These differences of observation may have resulted from differences in treatment times and concentrations (Dempsey and Walker, 1973, 1978). However, other important factors (e.g., treatment temperature), known to influence the effect of $\mathrm{NaOCl}$ on lettuce (Lactuca sativa L.) germination (Drew and Brocklehurst, 1984), have not been recorded.

Seeds of 'E-84066' sweet pepper from Enza Zaden, Holland, were isolated from fully mature fruits of plants cultivated in soil in plastic-covered greenhouses. After drying at room temperature $(27 \pm 5 \mathrm{C})$ to constant weight, seeds were enclosed in envelopes and stored in darkness at $25 \pm 3 \mathrm{C}$ until required. Sodium hypochlorite solutions were freshly prepared from Klinex (Lever, Athens, Greece), a commercial product containing $14.5 \% \mathrm{NaOCl}$.

Treatments were carried out on batches of 300 seeds that were immersed in $250 \mathrm{ml}$ of

Received for publication 13 Sept. 1991. Accepted for publication 4 Feb. 1992. The cost of publishing this paper was defrayed in part by the payment of page charges. Under postal regulations, this paper therefore must be hereby marked advertisement solely to indicate this fact. deionized water or $\mathrm{NaOCl}$ solution $(1 \%, 2 \%$, or $3 \%$ ) for up to 40 min while being stirred constantly. The solution was thermostatically maintained at 15,25 , or $35 \mathrm{C}$. Following treatment, the seeds were filtered out of solution and, except where otherwise indicated, washed with eight changes of deionized water. Total washing time was 4 min. After blotting off the liquid of the final wash with paper towels, six replicates of 50 seeds each were then placed on three layers of absorbent paper that had been moistened with $10 \mathrm{ml}$ deionized water in $9-\mathrm{cm}$ petri dishes.
The petri dishes were incubated in darkness at $25 \pm 1 \mathrm{C}$ in constant-temperature incubators (CDR, Athens, Greece). Germination was recorded daily for 18 to 20 days. In one experiment to determine the effect of incubation temperature on germination, the incubators were set at $15 \pm 1,25 \pm 1,30 \pm$ 1 , and $35 \pm 1 \mathrm{C}$, respectively. The criterion of germination in all experiments was visible protrusion of the radicle with a minimum length of $2 \mathrm{~mm}$.

For each germination test a completely randomized design with six replications was used. For each sample date, means were compared using the method of least significant differences or by determination of SE. The rate of germination was indicated by the $\mathrm{T}_{\mathrm{s}}$ value derived from graphs, which denotes the time required (days) to reach $50 \%$ of the final germination percentage.

When pepper seeds were treated with water or increasing concentrations of $\mathrm{NaOCl}$ for 5 or $40 \mathrm{~min}$ at $15 \mathrm{C}$ within 2 to 3 weeks of seed removal from the pod, the typical time courses of germination were sigmoid (Fig. 1). Treatment with $1 \%, 2 \%$, or $3 \% \mathrm{NaOCl}$ for $5 \mathrm{~min}$ had no significant effect on the rate or final percentage of germination (Fig. 1A) in comparison with the control (water). However, when treatment was carried out for $40 \mathrm{~min}$, both the rate of germination and the final germination level were increasingly inhibited with increasing concentrations of $\mathrm{NaOCl}$ (Fig. 1B). Stimulation of germination by $\mathrm{NaOCl}$ treatment was absent, as it was in other experiments using lower concentrations $(0.25 \%$ and $0.5 \%$ ) of $\mathrm{NaOCl}$ (data not shown). Omission of the standard washing procedure following treatment with $1 \%$ or $3 \% \mathrm{NaOCl}$ for $5 \mathrm{~min}$ had no significant effect $(P=0.05)$ on the rate or percentage of germination (Table 1). However, when treated
Table 1. Effect of washing on the rate of germination $\left(T_{50}\right)$ and on the final germination percentage of freshly isolated pepper seeds following treatment with $\mathrm{NaOCl}$ at $15 \mathrm{C}$.

\begin{tabular}{|c|c|c|c|c|c|}
\hline \multirow{3}{*}{$\begin{array}{l}\mathrm{NaOCl} \\
\text { concn } \\
(\%)\end{array}$} & \multirow{3}{*}{$\begin{array}{l}\text { Duration of } \\
\text { treatment } \\
\text { (min) }\end{array}$} & \multicolumn{4}{|c|}{ Seed } \\
\hline & & \multicolumn{2}{|c|}{ Final germination (\%) } & \multicolumn{2}{|c|}{$\mathrm{T}_{50}$ (days) } \\
\hline & & Unwashed & Washed & Unwashed & Washed \\
\hline $0\left(\mathrm{H}_{2} \mathrm{O}\right)$ & 5 & 92.0 & 91.0 & 6.6 & 6.7 \\
\hline 1 & 5 & 90.0 & 93.7 & 6.2 & 6.9 \\
\hline 3 & 5 & 93.3 & 90.0 & 6.6 & 6.6 \\
\hline $0\left(\mathrm{H}_{2} \mathrm{O}\right)$ & 40 & 94.0 & 93.3 & 7.1 & 7.5 \\
\hline 1 & 40 & 92.7 & 88.0 & 6.6 & 6.6 \\
\hline 3 & 40 & 70.0 & 73.3 & 11.1 & 8.5 \\
\hline $\operatorname{LSD}(P=0.05)$ & 5 & \multirow{2}{*}{\multicolumn{2}{|c|}{$\begin{array}{l}3.35 \\
3.37\end{array}$}} & \multicolumn{2}{|c|}{0.94} \\
\hline LSD $(P=0.05)$ & 40 & & & \multicolumn{2}{|c|}{0.73} \\
\hline
\end{tabular}

Table 2. Effect of incubation temperature on the rate of germination $\left(\mathrm{T}_{50}\right)$ and on the final germination percentage of freshly isolated pepper seeds following treatment with $\mathrm{NaOCl}$ at $35 \mathrm{C}$.

\begin{tabular}{|c|c|c|c|c|c|c|c|c|c|}
\hline \multirow{3}{*}{$\begin{array}{l}\mathrm{NaOCl} \\
\text { concn } \\
(\%)\end{array}$} & \multirow{3}{*}{$\begin{array}{l}\text { Duration of } \\
\text { treatment } \\
\text { (min) }\end{array}$} & \multicolumn{8}{|c|}{ Incubation temp $\left({ }^{\circ} \mathrm{C}\right)$} \\
\hline & & \multicolumn{4}{|c|}{ Final germination (\%) } & \multicolumn{4}{|c|}{$\mathrm{T}_{30}$ (days) } \\
\hline & & 15 & 25 & 30 & 35 & 15 & 25 & 30 & 35 \\
\hline $\begin{array}{l}0\left(\mathrm{H}_{2} \mathrm{O}\right) \\
1 \\
1 \\
3 \\
3\end{array}$ & $\begin{array}{r}20 \\
5 \\
20 \\
5 \\
20\end{array}$ & $\begin{array}{l}93.3 \\
90.7 \\
96.7 \\
96.0 \\
38.0\end{array}$ & $\begin{array}{l}92.0 \\
85.3 \\
89.3 \\
96.7 \\
71.3\end{array}$ & $\begin{array}{l}94.0 \\
92.0 \\
93.3 \\
97.3 \\
46.7\end{array}$ & $\begin{array}{l}84.7 \\
85.3 \\
88.0 \\
88.7 \\
27.3\end{array}$ & $\begin{array}{r}9.5 \\
12.4 \\
9.5 \\
10.3 \\
15.9\end{array}$ & $\begin{array}{l}4.3 \\
4.9 \\
4.7 \\
4.7 \\
7.0\end{array}$ & $\begin{array}{l}4.7 \\
4.8 \\
5.7 \\
4.6 \\
9.9\end{array}$ & $\begin{array}{r}6.5 \\
6.2 \\
8.2 \\
6.3 \\
10.9\end{array}$ \\
\hline \multicolumn{2}{|c|}{ LSD $(P=0.05)$} & 11.7 & 8.8 & 6.1 & 9.1 & 3.3 & 1.6 & 1.0 & 3.5 \\
\hline
\end{tabular}




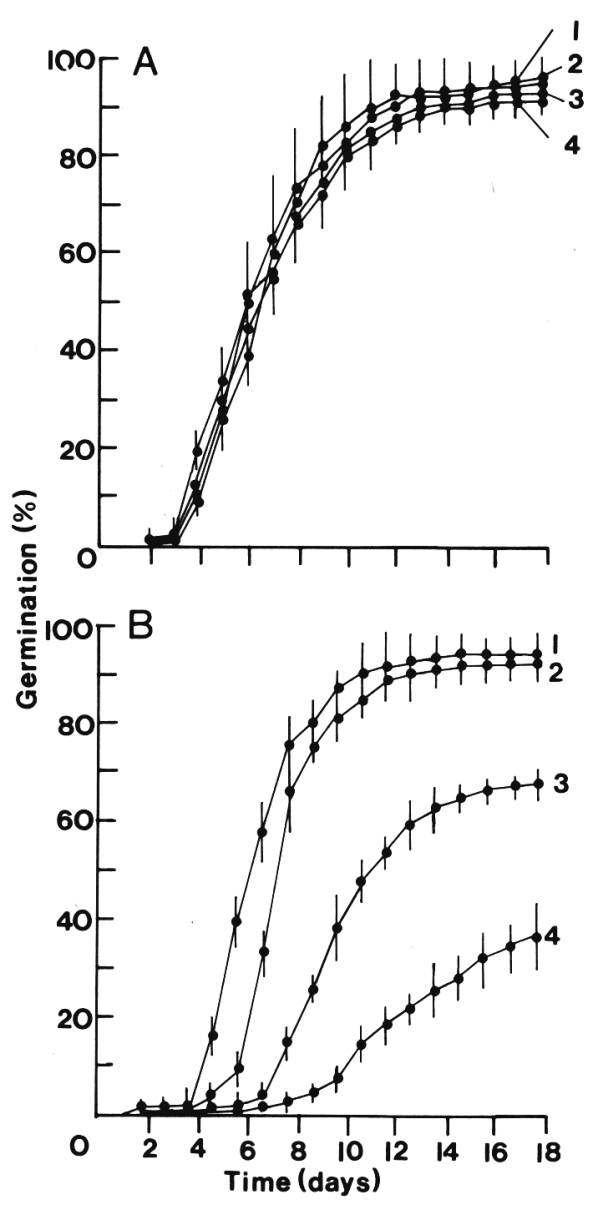

Fig. 1. Germination time courses at $25 \mathrm{C}$ of freshly isolated pepper seeds following treatment for 5 $\min (\mathrm{A})$ or $40 \mathrm{~min}(\mathrm{~B})$ at $15 \mathrm{C}$ with 1$) 0 \%$ water 2) $1 \% \mathrm{NaOCl}, 3) 2 \% \mathrm{NaOCl}$, or 4) $3 \% \mathrm{NaOCl}$. Vertical bars equal $\pm 1 \mathrm{SE}$.

with $3 \% \mathrm{NaOCl}$ for $40 \mathrm{~min}$, the $\mathrm{T}_{\mathrm{so}}$ of unwashed seed was higher than that of washed seed (indicative of a reduction in germination rate), but the total percentage germination was not significantly different.

When seeds were treated with $\mathrm{NaOCl}(1 \%$ or $3 \%$ ) for $5 \mathrm{~min}$, the total germination percentage and $\mathrm{T}_{\mathrm{so}}$ values were similar to those of the control (water), irrespective of treatment temperature (Fig. 2). Only at 35C did treatment with $3 \% \mathrm{NaOCl}$ for 5 min cause a significant increase in $\mathrm{T}_{50}$ (i.e., reduction in germination rate) in comparison with the control, but the final germination levels were not affected. However, when treatment was extended to 20 or $40 \mathrm{~min}, \mathrm{NaOCl}$ reduced the rate and final germination percentage of seed in comparison with the control, the degree of reduction depending on the treatment temperature and concentration. Reduction in the rate of germination (i.e., increase of $\mathrm{T}_{50}$ ) relative to water occurred with $1 \%$ and $3 \%$ $\mathrm{NaOCl}$, but was greater in the latter. Final germination at 15 or $25 \mathrm{C}$ was significantly lower than in the control only with $3 \% \mathrm{NaOCl}$. At 35C, no seed germinated after treatment with $3 \% \mathrm{NaOCl}$ for $40 \mathrm{~min}$.

Germination of the fresh ( 3 days after isolation) seed treated with $\mathrm{NaOCl}$ at $35 \mathrm{C}$ was progressively inhibited by increasing the duration of treatment (Fig. 3A). Thus, the $T_{50}$
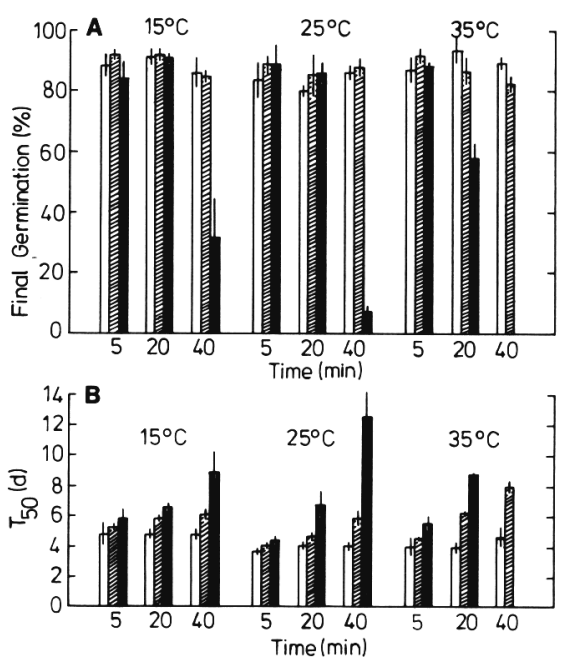

Fig. 2. Percentage germination after 20 days incubation at $25 C(\mathbf{A})$ and the $T_{50}$ values $(B)$ of freshly isolated pepper seeds following treatment with $0 \%$ water (white bars), $1 \% \mathrm{NaOCl}$ (hatched bars), or $3 \% \mathrm{NaOCl}$ (black bars) for 5,20 , or $40 \mathrm{~min}$ at 15,25 , or $35 \mathrm{C}$. Vertical bars equal $\pm 1 \mathrm{SE}$.

increased from 5.0 (control) to 7.8 days (20min treatment) and 14.5 days (30-min treatment). The total germination decreased from $98 \%$ (control) to $54 \%$ and $8 \%$ (20- and 30min $\mathrm{NaOCl}$ treatments, respectively). By contrast, the germination of seeds that had been stored for 10 months at $25 \pm 3 \mathrm{C}$ was inhibited substantially by $3 \% \mathrm{NaOCl}$ only when the duration of treatment was $>10$ min (Fig. 3B). The degree of inhibition of germination was invariably less than that of the corresponding treatment of the fresh seed.

When the effect of incubation temperature following $\mathrm{NaOCl}$ treatment at $35 \mathrm{C}$ was tested, significant reduction of final germination in comparison with the control was observed only after treatment with $3 \% \mathrm{NaOCl}$ for 20 min, regardless of incubation temperature (Table 2). Inhibition was greatest with incubation at $35 \mathrm{C}$ and least at $25 \mathrm{C}$. The $\mathrm{T}_{50}$ values of seeds treated with $3 \% \mathrm{NaOCl}$ for 20 min were significantly higher than those of the control, thus indicating a reduction in the rate of germination (Table 2). The $\mathrm{T}_{50}$ values were highest for seed incubated at 15 or $35 \mathrm{C}$. Differences in the $\mathrm{T}_{50}$ values for other treatments were mostly nonsignificant $(P=0.05)$.

In conclusion, germination behavior of pepper seed following treatment with $\mathrm{NaOCl}$ depended on: 1) the concentration of the $\mathrm{NaOCl}$ solution, 2) the duration of treatment, 3) the treatment temperature, 4) the age of the seed, and 5) the incubation temperature during germination.

Inhibition of the rate and percentage of germination by $3 \% \mathrm{NaOCl}$ is in agreement with previous findings (Dempsey and Walker, 1973; McCollum and Linn, 1955). Stimulation of germination, as reported by Fieldhouse and Sasser (1975) and Macit (1981), was not observed here.

In the previous studies noted, treatment temperatures were not recorded. However, it has been shown that this is an important

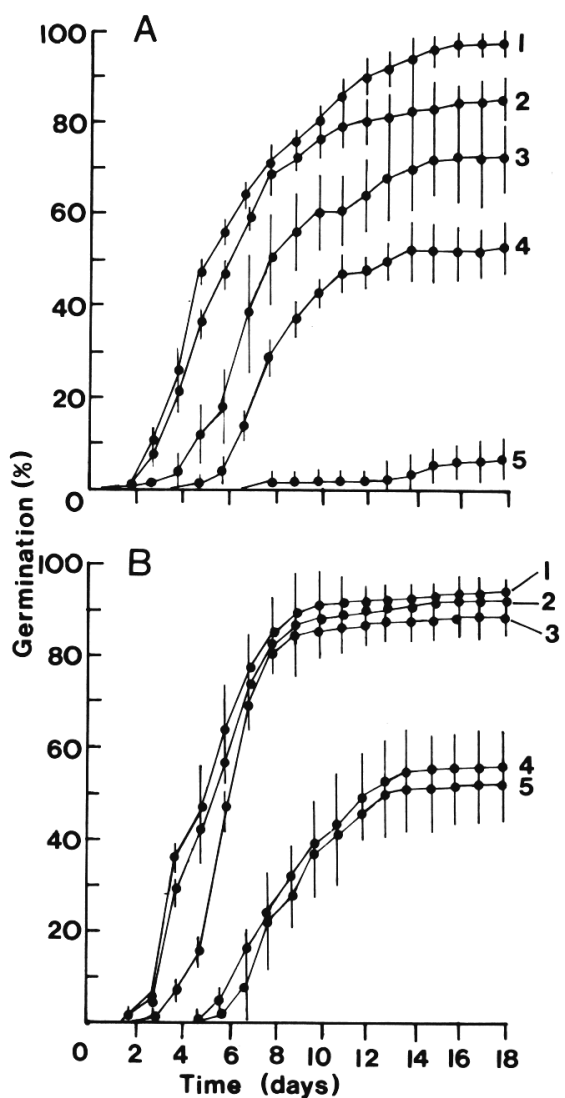

Fig. 3. Germination time courses at $25 \mathrm{C}$ of $(\mathbf{A})$ freshly isolated pepper seed and (B) pepper seed that had been stored for 10 months at ambient temperature. Seeds were treated with water for 1) $30 \mathrm{~min}$ or $3 \% \mathrm{NaOCl}$ for 2) $5 \mathrm{~min}, 3) 10$ $\mathrm{min}$, 4) $20 \mathrm{~min}$, or 5) $30 \mathrm{~min}$ at $35 \mathrm{C}$. Vertical bars equal $\pm 1 \mathrm{SE}$.

factor that influences the sensitivity of lettuce seed to $\mathrm{NaOCl}$ treatment (Drew and Brocklehurst, 1984). Dempsey and Walker (1973) treated pepper seeds immediately after harvest with $\mathrm{NaOCl}$ and stored them for 56 days before starting germination tests. In other studies, the age of the seed was not reported (Cantliffe and Watkins, 1983; Fieldhouse and Sasser, 1975). The data presented here show that both treatment temperature and seed age influenced the degree of inhibition caused by $\mathrm{NaOCl}$. Inhibition was also influenced by the incubation temperature during germination. It is important, therefore, that these factors be taken into consideration when $\mathrm{NaOCl}$ treatments are undertaken. Since the primary purpose of $\mathrm{NaOCl}$ is to provide surface sterilization of seeds (Dempsey and Walker, 1973, 1978), it is essential that sterilization does not inhibit germination. We suggest that, for pepper seeds, treatment with $3 \% \mathrm{NaOCl}$ at 15 to $25 \mathrm{C}$ for up to $20 \mathrm{~min}$ would not inhibit germination.

\section{Literature Cited}

Cantllffe, D.J. and J.T. Watkins. 1983. More rapid germination of pepper seeds after seed treatment. Proc. Fla. State Hort. Soc. 96:99-101.

Dempsey, A.H. and J.T. Walker. 1973. Efficacy of calcium and sodium hypochlorite for seed treatment of pepper. HortScience 8:328-329. 
Dempsey, A.H. and J.T. Walker. 1978. Calcium and sodium hypochlorite for pepper seed treatment. Res. Rpt. 280, Georgia Agr. Expt. Sta., Experiment.

Drew, R.L.K. and P.A. Brocklehurst. 1984. The effect of sodium hypochlorite on germination of lettuce seed at high temperature.
J. Expt. Bot. 35:975-985.

Fieldhouse, D.J. and M. Sasser. 1975. Stimulation of pepper seed germination by sodium hypochlorite treatment. HortScience 10:622.

Macit, F. 1981. Stimulation of pepper seed germination by some chemicals and growth regulators. Acta Hort. 111:139.
McCollum, J.P. and M.B. Linn. 1955. Bleaching and disinfecting discolored pepper seed with sodium hypochlorite. Proc. Amer. Soc. Hort. Sci. 66:345-349.

Thomas, T.H. 1981. Seed treatments and techniques to improve germination. Scientific Hort. 32:47-59. 